\title{
JOURNAL.RU
}

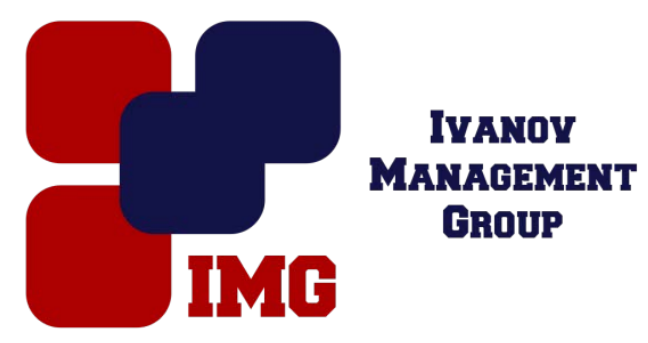

\author{
Акбашева Д.М., Деккушева 3.Д., Черкасова М.Ю. \\ Северо-Кавказская государственная гуманитарно технологическая академия \\ Черкесск, Россия
}

doi: 10.18411/lj-30-04-2017-1-02

idsp 000001:lj-30-04-2017-1-02

\section{Финансирование долгосрочных инвестиции}

Финансовые инвестиции представляют собой вложения средств в разнообразные финансовые активы. Под финансовым активом в обширном смысле уясняют любое законодательно признанное соглашение, отражающее отношения владения или займа. На нынешний день главной задачей организации является формирование адекватной рынку конкурентной среды на основе стабильного обновления технологических процессов, стремление к инновационному развитию, уменьшению затрат производства и выпуска конкурентоспособной продукции. Для достижения предоставленных целей, вложения в инвестиции по имеющимся оценкам, намного эффективнее, чем вложения в основные фонды.

Источниками финансирования долгосрочных инвестиций являются собственные средства инвесторов и привлеченные.

К собственным средствам относятся:

- прибыль, остающаяся в распоряжении организации после уплаты налогов;

- по основным средствам и нематериальным активам амортизационные отчисления.

- полученные в покрытие потерь и убытков от страховых случаев, страховые возмещения.

- бюджетные ассигнования и средства внебюджетных фондов, полученные на безвозвратной основе.

При нехватке собственных источников финансирования инвесторы могут отражать временно средства других юридических и физических лиц в виде 
займов и кредитов, а также средства из бюджета и внебюджетных фондов, предоставляемых на возвратной основе.

В плане счетов бухгалтерского учета не предусмотрен для учета амортизационных отчислений синтетический счет, хотя они являются одним из важнейших источников собственных средств финансирования долгосрочных инвестиций. В связи с этим учет движения и остатка амортизационных отчислений рекомендуется вести на забалансовом счете «Амортизация основных средств» с раздельным учетом суммы амортизации по основным средствам производственного и непроизводственного назначения. Этот счет дебетуется на сумму начисленной амортизации, кредитуется, при их использовании на финансирование.

Амортизационные отчисления могут включить при расчете себестоимости услуг и товаров, по данной причине амортизация входит в состав выручки от реализации. В следствии чего, она поступает в кассу предприятия или на ее счет в одном из банков. Денежные средства эти могут применяться с целью финансирования капитальных вложений в основные средства и нематериальные активы (счет 01,04).

Амортизация по основным средствам и нематериальным активам - второй крупный и наиболее постоянный источник финансового обеспечения капиталовложений. В отличие от прибыли данный источник не зависит от результатов финансирования хозяйственной деятельности предприятий. Амортизационные отчисления призваны снабжать не только простое, но и расширенное воспроизводство основного капитала. Предприятие вправе использовать амортизационные отчисления на:

- модернизацию и обновление выпускаемой продукции для повышения уровня ее конкурентоспособности;

- получение нематериальных активов и др.

Однако в большей степени предприятия расходуют эти денежные средства с расчетного счета не по целевому назначению, например на пополнение материально-производственных запасов.

Для более действенного использования этих отчислений в качестве инвестиционного ресурса многие предприятия проводят соответствующую амортизационную политику, следующие три элемента включают:

- определение приоритетных направлений использования амортизационных отчислений; 
- учет амортизационных отчислений при оценке эффективности инвестиционных проектов в составе чистых денежных поступлений;

- обновление основного капитала и другие параметры хозяйственной деятельности, оценка эффективности амортизационной политики для установления ее влияния на финансовые результаты.

На эффективность инвестиционной политики организации влияют следующие три фактора:

- в результате малых коэффициентов обновления основного капитала (1-3\% в год) в его массе сохраняется и доля физически изношенных элементов;

- долгосрочных инвестиций приводят с низкими темпами роста к слабому приросту элементов основного капитала, в следствии чего замедляется формирование амортизационных отчислений;

- инновационно-активные предприятия нечасто используют способы ускоренной амортизации, чтобы по быстрее обновлялись активные элементы основного капитала (счет 10).

Таким образом, амортизационные отчисления с одной стороны являются элементами текущих издержек и участвуют в формировании прибыли предприятия. Они выступают налоговыми вычетами и позволяют исключить из налогооблагаемой базы назначенную сумму его доходов, с другой стороны.

\section{Литература}

1. Инвестиции: Учеб. пособие / Под ред. М.В. Чиненова. - М.: КноРус, 2013.

2. Меркулов, Я.С. Инвестиции: учебное пособие /Я.С. Меркулов.- М.: ИНФРА-М, 2013.

3. Нешитой, А. С. Инвестиции: Учебник/А.С. Нешитой. - 6-е изд., перераб. и испр. - М.: Издательско-торговая корпора-ция «Дашков и К0», 2013. 